\title{
Expression, Activity, and Function of Phosphodiesterases in the Mature and Immature Ductus Arteriosus
}

\author{
HANGUAN LIU, VINCENT MANGANIELLO, NAHID WALEH, AND RONALD I. CLYMAN \\ Laboratory of Cellular Metabolism [H.L., V.M.], National Heart, Lung, and Blood Institute, Bethesda, Maryland 20892; \\ SRI International [N.W.], Menlo Park, California 94025; Department of Pediatrics [R.I.C.], University of California San Francisco,
} San Francisco, California 94143

\begin{abstract}
A patent ductus arteriosus is due in large part to increased sensitivity of the premature ductus to PGE2. After PGE2 stimulation, cAMP concentrations are higher in the immature than in the mature ductus. cAMP concentrations depend on the rates of adenyl cyclase production and phosphodiesterase (PDE)-mediated degradation. We used ductus from immature $(n=25)$ and mature $(n=21)$ fetal sheep to investigate whether a developmental increase in PDE activity could explain the diminished cAMP accumulation that follows PGE2 stimulation in the mature ductus. With advancing gestation, mRNA expression of the smooth muscle PDE isoforms (PDE1A, 1B, 1C, 3A, 3B, 4D, and 5A) increased in the ductus as did their hydrolytic activities. Selective inhibitors of PDE1, PDE3, and PDE4 relaxed the mature and immature ductus in the presence of inhibitors of prostaglandin and nitric oxide production. The mature ductus required higher concentrations of each of the PDE inhibitors to inhibit its tension to the same extent as in the immature ductus. There were no developmental changes in PDE expression in the fetal aorta. In conclusion, we observed a developmental increase in cAMP and cGMP PDE activity that contributes to the decreased sensitivity of the late-gestation ductus arteriosus to vasodilators like PGE2. (Pediatr Res 64: 477-481, 2008)
\end{abstract}

$\mathrm{P}$ reterm infants have a higher incidence of patent ductus arteriosus (PDA) than term infants. In large part, this is because of the increased sensitivity of the premature ductus to prostaglandin (PG) E2 $(1,2)$. In the lamb, pig, and baboon ductus arteriosus, PGE2 exerts its effects through three selective G-protein coupled receptors (EP2, EP3D, and EP4) that activate adenyl cyclase $(3,4)$. The increased sensitivity of the immature ductus appears to be due to the differences in cAMP signaling: 1) EP receptor stimulation in the immature ductus produces higher concentrations of cAMP and protein kinase A-mediated relaxation than are found in the mature ductus, and 2) the immature ductus loses its increased sensitivity to PGE2 and behaves like the mature ductus in the presence of inhibitors of Protein Kinase A (3).

Received March 28, 2008; accepted May 23, 2008

Correspondence: Ronald I. Clyman, M.D., University of California San Francisco, 513 Parnassus Ave., Room 1408 HSW, UCSF Box 0544, San Francisco, CA 94143; e-mail: clymanr@peds.ucsf.edu

Supported by grants from U.S. Public Health Service (NIH grants HL46691, HL56061) and by a gift from the Jamie and Bobby Gates Foundation.
Intracellular levels of cAMP are regulated by adenyl cyclases and cyclic nucleotide phosphodiesterases (PDE). We recently reported that the increased concentration of cAMP that follows PGE2 stimulation of the immature ductus does not appear to be due to the increased EP receptor expression or increased adenyl cyclase activity (3). In the current study, we investigated whether alterations in PDE-mediated cAMP breakdown might play a role in the increased cAMP concentrations that result from PGE2 stimulation of the immature ductus.

There are at least 11 distinct PDE families that encode more than 50 different PDE enzyme variations $(5,6)$. Depending on the species, the major PDEs present in vascular smooth muscle are PDE1A, 1B, and 1C, PDE3A and 3B, PDE4D, and PDE5A $(7,8)$. These PDEs are differentially controlled by cAMP, cGMP, and calcium/calmodulin $(7,9)$. The PDE1 isoforms are stimulated by calcium/calmodulin; they include PDE1A and 1B (which selectively hydrolyze cGMP), and PDE1C (which hydrolyzes cAMP and cGMP equally well). The PDE3 isoforms, $3 \mathrm{~A}$ and $3 \mathrm{~B}$, preferentially hydrolyze cAMP; their hydrolytic activities are competitively inhibited by cGMP because their catalytic sites have similar affinities for cAMP and cGMP (5). This allows vasodilators like nitric oxide that activate guanyl cyclase, to synergize with adenyl cyclase activating agents like PGE2. PDE4D isoforms specifically hydrolyze cAMP and are not regulated by cGMP. The PDE5A isoform selectively hydrolyzes cGMP and effectively controls cGMP signaling under conditions of low calcium. Under conditions of elevated calcium, PDE1A, 1B, and 1C are likely to play an increasingly important role.

Previous studies have shown that PDE inhibition can relax the ductus areriosus in animals and humans (Paradisis M, Evans N, Kluckow M, Osborn DA, unpublished observations), both in vitro $(10)$ and in vivo $(11,12)$. In the following study, we used ductus from immature $(n=25)$ and mature $(n=21)$ fetal sheep to investigate whether a developmental increase in PDE activity

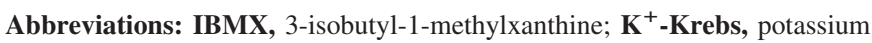
Kreb's solution; MAT, maximal active tension; 8-MM-IBMX, 8-methoxymethyl 3-isobutyl-1-methylxanthine; MY5445, 1-(3-chlorophenylamino)-4phenylphthalazine; PDE, phosphodiesterase; PGE2, prostaglandin E2 
could explain the diminished cAMP accumulation that follows PGE2 stimulation in the mature ductus.

\section{METHODS}

Twenty-one late-gestation sheep fetuses (mixed Western breed: $137 \pm 5 \mathrm{~d}$ gestation, term $=145 \mathrm{~d}$, mean $\pm \mathrm{SD})$ and 25 immature fetuses $(105 \pm 3 \mathrm{~d})$ were delivered by cesarean section and anesthetized with ketamine $\mathrm{HCl}$ (30 mg/kg IV) before rapid exsanguination. These procedures were approved by the Committee on Animal Research at the University of California, San Francisco.

Preparation of total RNA, reverse transcription, and quantitative polymerase chain reaction. Total RNA was isolated from the frozen ductus and aorta of seven immature and seven mature fetuses as described elsewhere (4). We used the TaqMan Universal PCR master mix of PE Applied Biosystems (Foster City, CA) to quantify the expression of the PDE isoforms (PDE1A, 1B, 3A, 3B, 4D, 5A). Taqman probes were designed using the Primer Express program and labeled with fluorophores FAM (6-caboxy-fluorescein) and TAMRA (6-carboxy-tetramethyl-rhodamine) as reporter and quencher dyes, respectively. An ABI PRISM 7500 Sequence detection system was used to determine the cycle threshold (CT). Reactions were carried out in triplicates. Data were analyzed using the Sequence Detector version 1.6.3 program. Malate dehydrogenase (MDH) was used as an internal control to normalize the data (3).

Phophodiesterase activity measurements. Ductus from five immature and five mature fetuses were homogenized on ice in lysis buffer containing 50-mM HEPES ( $\mathrm{pH} 7.4$ ), $1 \%$ Triton X-100 and protease inhibitor cocktail from Sigma Chemical Co. (Catalog Number:P8340), and spun at 3000 $g$ for 10 $\min$ at $4^{\circ} \mathrm{C}$. The resulting supernatant was used for protein and PDE assays. Protein concentration was determined by Bio-Rad Detergent Compatible Protein assay kit.

Ten micrograms of protein from the supernatant were used for the cAMP PDE or cGMP PDE assays. The assay mixture $(100 \mu \mathrm{L}$ volume containing $50 \times 10^{-3}$ M HEPES (pH 7.4), $10 \times 10^{-3} \mathrm{M} \mathrm{MgCl}_{2}, 1 \times 10^{-3} \mathrm{M}$ EDTA, $0.1 \times 10^{-3} \mathrm{M}$ EGTA, and $1 \times 10^{-6} \mathrm{M}^{3} \mathrm{H}-\mathrm{cAMP}(30,000 \mathrm{CPM})$ or $1 \times 10^{-6}$ $\mathrm{M}^{3} \mathrm{H}$-cGMP (30,000 CPM)) was incubated at $30^{\circ} \mathrm{C}$ for $20 \mathrm{~min}$. The assays were terminated by adding $50 \mu \mathrm{L}$ of ice-cold, $0.5 \mathrm{M}$ EDTA (pH 8.0). After diluting the samples with $0.3 \mathrm{~mL}$ of buffer $(0.1 \mathrm{M} \mathrm{NaCl}, 0.1 \mathrm{M}$ HEPES (pH $8.5)$ ), the reaction product, either $5^{\prime}-\left[{ }^{3} \mathrm{H}\right]$ AMP or $5^{\prime}-\left[{ }^{3} \mathrm{H}\right] \mathrm{GMP}$, was purified by polyacrylamide-boronate gel chromatography (affi-Gel 601, 1-mL bed volume) and quantified by liquid scintillation counting.

PDE activity, for each of the PDE families, was determined as that portion of total cAMP or cGMP hydrolysis that was inhibited by selective PDE inhibitors $\left(1 \times 10^{-6} \mathrm{M}\right.$ cilostamide for PDE3 activity, $5 \times 10^{-6} \mathrm{M}$ rolipram for PDE4 activity, and $5 \times 10^{-6}$ M MY5445 (1-(3-chlorophenylamino)-4phenylphthalazine) for PDE5 activity) or activators $\left(4 \times 10^{-3} \mathrm{M} \mathrm{CaCl}_{2}\right.$ and 10 units of calmodulin for PDE1 activity). No EGTA was added to the assay mixture when calcium/calmodulin stimulated PDE1 activity was being measured.

In vitro isometric contractility studies. The ductus arteriosus from 13 immature $(106 \pm 2 \mathrm{~d}$ gestation) and nine mature $(139 \pm 3 \mathrm{~d})$ fetuses were divided into $1-\mathrm{mm}$ thick rings (2-3 rings per animal) and isometric tension was measured in a Krebs-bicarbonate solution $\left(\left[\times 10^{-3} \mathrm{M}\right]: 118 \mathrm{NaCl}, 4.7\right.$ $\mathrm{KCl}, 2.5 \mathrm{CaCl}_{2}, 0.9 \mathrm{MgSO}_{4}, 1 \mathrm{KH}_{2} \mathrm{PO}_{4}, 11.1$ glucose, $\left.23 \mathrm{NaHCO}_{3}[\mathrm{pH} 7.4]\right)$ containing indomethacin $\left(5 \times 10^{-6} \mathrm{M}\right)$ and $\mathrm{N} \omega$-nitro-arginine methyl ester (L-NAME, $10^{-4} \mathrm{M}$ ), to inhibit endogenous prostaglandin and nitric oxide production, respectively (13). The bath solution was equilibrated with $5 \%$ $\mathrm{CO}_{2} / 30 \% \mathrm{O}_{2}$ balance $\mathrm{N}_{2}$ and was changed every $20 \mathrm{~min}$. Rings were stretched to initial lengths (preterm $=5.4 \pm 0.3 \mathrm{~mm}$; late-gestation $=6.7 \pm 0.6 \mathrm{~mm}$ ) that produce maximal contractile responses when exposed to potassium Kreb's solution $\left(\mathrm{K}^{+}\right.$-Krebs) (containing $0.1 \mathrm{M} \mathrm{KCl}$ substituted for an equimolar amount of $\mathrm{NaCl}$ ), equilibrated with $95 \% \mathrm{O}_{2}(14)$. After the rings reached a steady-state tension (approximately 100-120 min), $\mathrm{K}^{+}$-Krebs solution was used to measure the maximal contraction that could be developed by the ductus (maximal contraction).

After the maximal contraction, the $\mathrm{K}^{+}$-Krebs solution was removed from the baths and the rings relaxed to a steady-state tension (baseline tension). We measured the ability of the PDE inhibitors to relax the ductus from the baseline tension. Cumulative dose-response curves were constructed for 8-methoxymethyl 3-isobutyl-1-methylxanthine (8-MM-IBMX, a PDE1 inhibitor), cilostamide (a PDE3 inhibitor), milrinone (a PDE3 inhibitor), rolipram (a PDE4 inhibitor), and MY5445 (a PDE5 inhibitor). The concentrations that produced $50 \%$ of maximal relaxation $\left(\mathrm{EC}_{50}\right.$ values) were determined from each dose-response curve. In all experiments, we allowed the tension in the rings to reach a new steady-state plateau after addition of a drug and before another concentration was added to the bath. Sodium nitroprusside $\left(10^{-4} \mathrm{M}\right)$ was added to each ring at the end of the experiment to determine its minimal tension. After the experiment, the tissues were removed from the baths and blotted dry and their wet weights determined. The immature ductus rings had a similar wet weight $(30 \pm 6 \mathrm{mg})$ as the mature rings $(34 \pm 10 \mathrm{mg})$.

The difference in tensions between the maximal tension (produced by $\mathrm{K}^{+}$-Krebs $/ 95 \% \mathrm{O}_{2}$ ) and the minimal tension (with sodium nitroprusside) was considered the maximal active tension (MAT) that the rings were capable of developing. The immature ductus rings developed significantly lower amounts of MAT than the mature ductus rings $(18.8 \pm 2.5 \mathrm{~g}$ compared with $23.1 \pm 4.2 \mathrm{~g}$, respectively, $p<0.01$ )

The difference in tensions between the baseline tension (before the PDE inhibitor dose-response cuve) and the minimal tension (with sodium nitroprusside) was considered the baseline Net Tension for the dose-response cuve. The baseline Net Tensions for the dose-response curves were similar in the immature and mature ductus (immature baseline Net Tension $=75 \pm 10 \%$ of MAT; mature $=81 \pm 9 \%$ of MAT).

MY5445 and 8-MM-IBMX were obtained from Biomol International (Plymouth Meeting, PA). All other chemicals were from Sigma Chemical Co. Chemical (St. Louis, MO).

Statistics. Statistical analyses of unpaired and paired data were performed by the appropriate $t$ test and by analysis of variance. Scheffe's test was used for post hoc analysis. Values are expressed as mean \pm SD. Drug concentrations refer to their final molar concentration in the bath.

\section{RESULTS}

The fetal ductus arteriosus expressed several PDE family isoforms (PDE1, PDE3, PDE4, and PDE5) (Fig. 1). The expression of each isoform increased with advancing gestation. In contrast, in the fetal aorta, there was no significant change in PDE expression with advancing gestation. The expression of most PDE isoforms was lower in the near term aorta than in the near term ductus (Fig. 1).

Basal cAMP and cGMP PDE activities were measured in ductus homogenates in the presence of $1 \times 10^{-6} \mathrm{M}$ cAMP and $1 \times 10^{-6} \mathrm{M}$ cGMP, respectively. The nonselective PDE antagonist, 3-isobutyl-1-methylxanthine, inhibited more than $97 \%$ of the ductus' basal PDE activity $(n=3$, data not
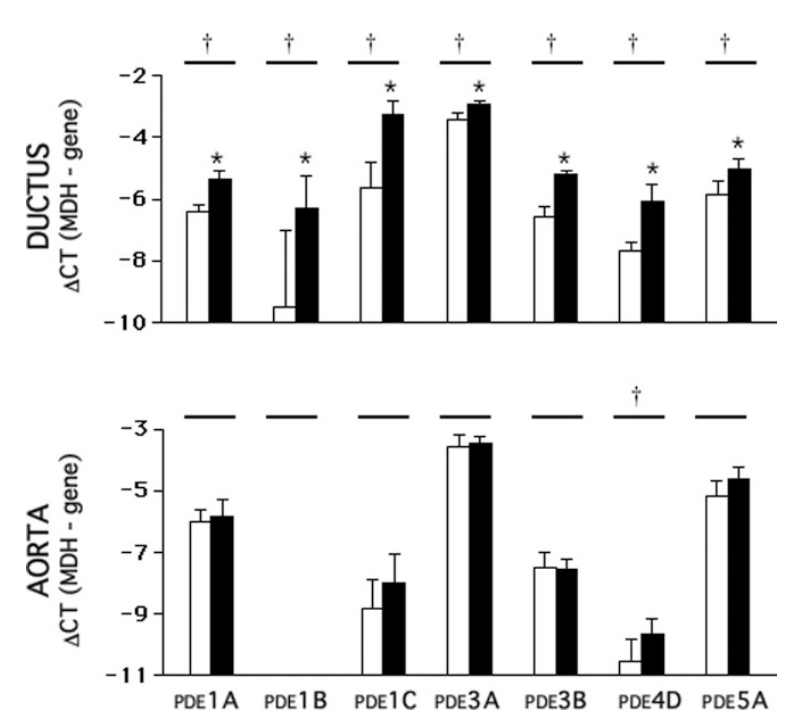

Figure 1. Real-time PCR measurements of PDE isoforms (PDE1A, 1B, 3A, $3 \mathrm{~B}, 4 \mathrm{D}, 5 \mathrm{~A})$ are greater in the mature $(\square)$ than in the immature ductus $(\square)$ arteriosus. $\triangle \mathrm{CT}(\mathrm{MDH}-\mathrm{gene})$ represents the difference in $\mathrm{CT}$ between the expression of the housekeeping gene $\mathrm{MDH}$ and the gene of interest. Each unit of $\Delta \mathrm{CT}(\mathrm{MDH}-\mathrm{gene})$ represents a 2 -fold increase in a gene's mRNA. The more negative the $\triangle \mathrm{CT}(\mathrm{MDH}$-gene), the fewer the number of starting copies of a gene (mRNA). $N=$ number of separate animals used (immature $=7$; mature $=7$ ). ${ }^{*} p<0.05$, mature ductus compared with mature aorta. $\dagger p<$ 0.05 , immature compared with mature. 

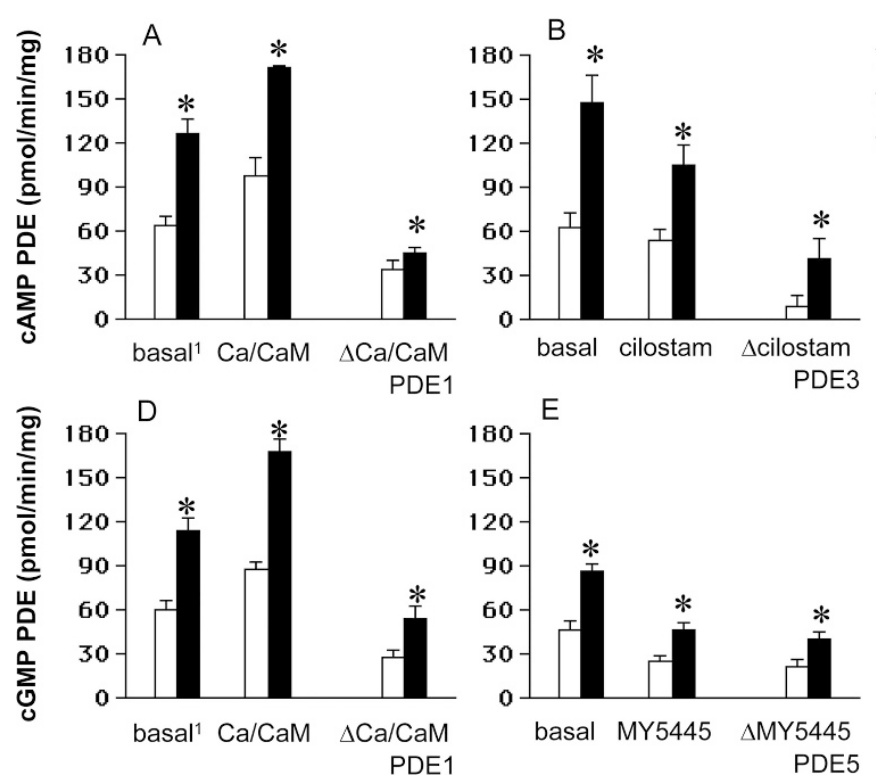

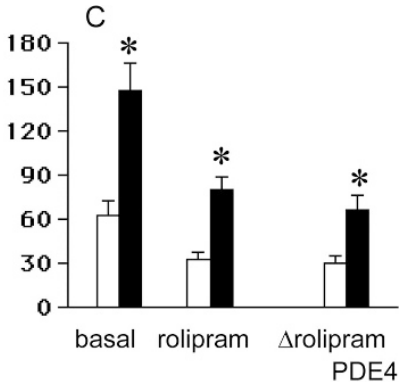

PDE4
Figure 2. cAMP and cGMP PDE activities are greater in the mature ( $\square$ ) than in the immature ductus $(\square)$ arteriosus. Ductus homogenates were incubated in assay buffer containing either ${ }^{3} \mathrm{H}$-cAMP (panels $A, B$, and $C$ ) or ${ }^{3} \mathrm{H}-\mathrm{cGMP}$ (panels $D$ and $E$ ). PDE activity was measured either in the absence (basal) or presence of selective PDE inhibitors (cilostamide $1 \times 10^{-6} \mathrm{M}$, for PDE3; rolipram $5 \times 10^{-6} \mathrm{M}$, for PDE4; and MY5445 $5 \times 10^{-6} \mathrm{M}$, for PDE5); or activators $\left(\mathrm{CaCl}_{2} /\right.$ calmodulin $(4 \times$ $10^{-3} \mathrm{M} / 10$ units, respectively), for PDE1). We determined the PDE activity for each PDE family $(\Delta)$ by subtracting the basal activity from the activity in the presence of inhibitor or activator. Basal ${ }^{1}$ : no EGTA was added to the assay buffer in $\mathrm{CaCl}_{2} /$ calmodulin experiments (see Methods). $N=$ number of separate animals used (immature $=5$; mature $=5$ ). $* p<$ 0.05 , immature compared with mature. shown). Both the basal cAMP and the basal cGMP PDE activities, as well as the activities attributed to PDE3 ( $\Delta$ cilostamide), PDE4 ( $\Delta$ rolipram), and PDE5 ( $\Delta$ MY5445) were significantly increased in the mature ductus compared with the immature ductus (Fig. 2). To assess the presence of PDE1 in ductus homogenates, we tested the effect of calcium/ calmodulin on both cAMP and cGMP hydrolytic activities. Calcium/calmodulin produced a greater stimulation of both cAMP and cGMP hydrolytic activities $(\Delta \mathrm{Ca} / \mathrm{CaM})$ in the mature ductus than in the immature ductus (Fig. 2).
Under normoxic conditions $\left(30 \% \mathrm{O}_{2}\right)$, in the presence of inhibitors of prostaglandin and nitric oxide production, the ductus arteriosus developed an active tension that was approximately $75-80 \%$ of its MAT (see Methods). Selective inhibitors of PDE1 (8-MM-IBMX), PDE3 (cilostamide and milrinone), and PDE4 (rolipram) relaxed the ductus in both the mature and immature ductus (Fig. 3). The selective PDE5 inhibitor MY5445 had no effect on ductus tension. Higher concentrations of 8-MM-IBMX (PDE1), cilostamide, milrinone (PDE3), and rolipram (PDE4) were needed to inhibit
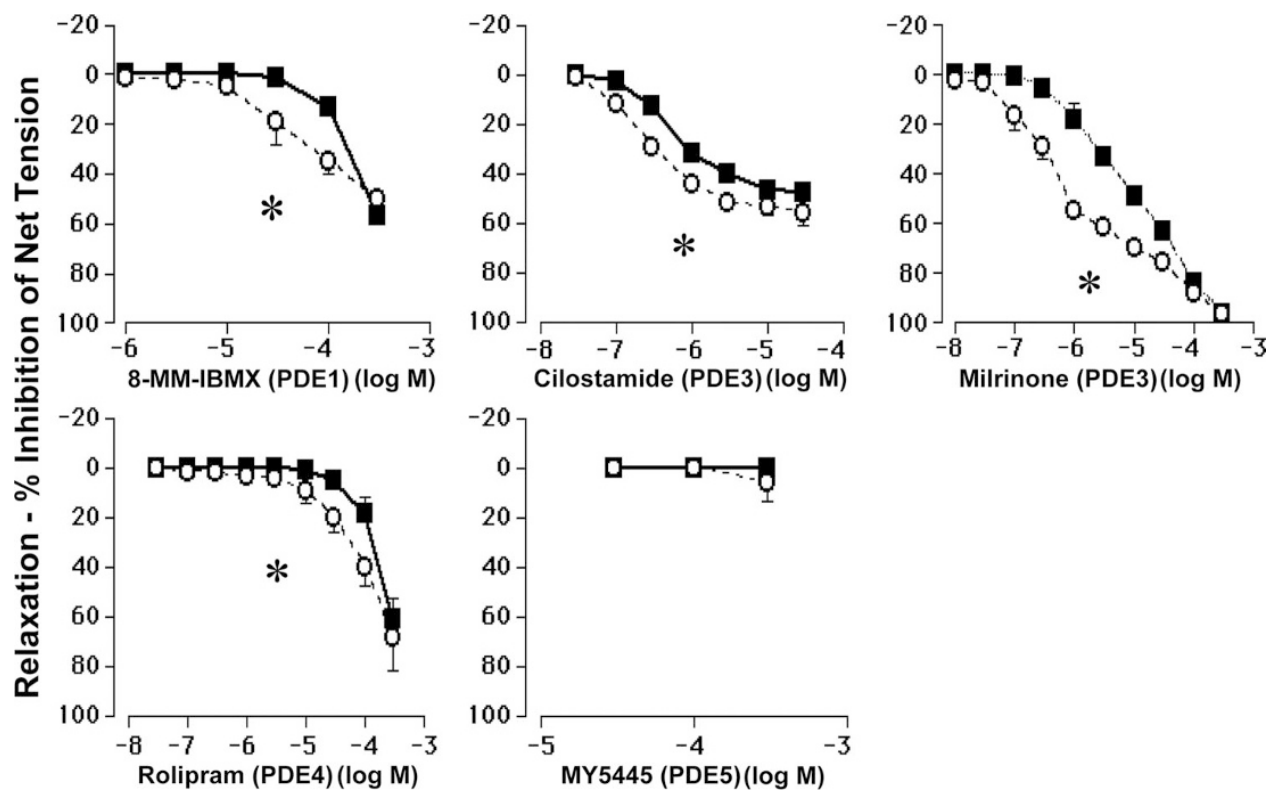

Figure 3. Higher concentrations of PDE1, 3, and 4 inhibitors are required to inhibit isometric tension in the mature ductus arteriosus (ם) than in the immature ductus $(\bigcirc)$. Ductus rings were precontracted with 30\% oxygen, indomethacin, and L-NAME (see Methods). Dose responses for 8-MM-IBMX, cilostamide, milrinone, rolipram, and MY5445 were studied. Tension is expressed as a percentage of baseline Net Tension (see Methods). ${ }^{*} p<0.05$, EC50 (immature) $<$ EC50 (mature). $n=$ number of separate animals used. 8-MM-IBMX: EC50 (immature) $=0.4 \pm 0.4 \times 10^{-4} \mathrm{M}(n=6)$; EC50 (mature) $=1.5 \pm 0.7 \times 10^{-4}$ $\mathrm{M}(n=5), p<0.05$. Cilostamide: EC50 (immature) $=2.9 \pm 0.8 \times 10^{-7} \mathrm{M}(n=4)$; EC50 (mature) $=8.4 \pm 1.5 \times 10^{-7} \mathrm{M}(n=4), p<0.05$. Milrinone: EC50 (immature $)=0.7 \pm 0.1 \times 10^{-6} \mathrm{M}(n=6) ; \mathrm{EC} 50$ (mature) $=9.4 \pm 2.2 \times 10^{-6} \mathrm{M}(n=7), p<0.05$. Rolipram: EC50 (immature $)=0.7 \pm 0.1 \times 10^{-4}$ $\mathrm{M}(n=6) ; \mathrm{EC} 50$ (mature) $=1.3 \pm 0.1 \times 10^{-4} \mathrm{M}(n=7), p<0.05$. MY5445: EC50 (immature) $=$ not measurable $(n=4)$; EC50 (mature) $=$ not measurable $(n=4)$ 
tensions in the mature ductus than in the immature ductus (Fig. 3).

\section{DISCUSSION}

An increase in cAMP or cGMP is generally associated with smooth muscle relaxation through both calcium-dependent and calcium independent processes (15-17). Consequently, an increase in PDE activity should result in a blunted relaxation. Our findings support the hypothesis that increasing PDE activity may contribute to the decreased ability of PGE2 to relax the ductus with advancing gestation. In the mature ductus, there was both increased expression (Fig. 1) and increased activity (Fig. 2) of all of the PDE isoforms: PDE1, 3, 4, and 5. In parallel with the increase in PDE activity, higher concentrations of PDE inhibitors were needed to produce the same degree of relaxation with advancing gestation (Fig. 3). Our observation that the mature ductus, in vitro, requires higher concentrations of PDE inhibitors to produce a similar relaxation as in the immature ductus is consistent with a prior report for PDE3 inhibition in the fetal rat, in vivo (11).

Several of our findings deserve further discussion. Although PDE1A and PDE1B, which hydrolyze cGMP, have frequently been observed in adult and newborn vascular tissues, PDE1C which hydrolyzes both cAMP and cGMP has not (18). In contrast, fetal vessels appear to express PDE1C (Fig. 1) (19). With advancing gestation, we observed both increased expression of PDE1C and increased calcium/calmodulin stimulation of cAMP hydrolysis in the ductus. This is consistent with increased PDE1C activity. Currently, it is difficult to assess the relative role of PDE1C in ductus contractility because available inhibitors of PDE1, like 8-MM-IBMX, have poor selectivity among the different PDE1 isoforms and are less potent against the PDE1C enzyme than against PDE1A or PDE1B $(20,21)$. However, the increased expression of PDE1C in the ductus (compared with the aorta) may make it a useful target for selective regulation of cyclic nucleotide signaling after birth.

PDE3 plays an important role in coordinating and amplifying the vasodilatory effects of agents that increase cAMP and cGMP. Uninhibited PDE3 activity has been found to promote vasoconstriction and neointima accumulation $(5,22-25)$. The increase in ductus arteriosus PDE3 activity with advancing gestation (Figs. 1 and 2) may contribute to the vasoconstriction and neointima formation that occur as term approaches (26).

The results of our contractility studies differed significantly from those of previous reports $(10,12)$ with regard to the effects of inhibition of PDE5 on ductus tension. We found that even though PDE5 was expressed in the wall of the fetal ductus (Figs. 1 and 2), inhibition of PDE5 had almost no effect on ductus contractility. Our contractility studies, however, were performed under different conditions than the previous studies $(10,12)$. We examined the contractility of ductus rings in the presence of inhibitors of endogenous prostaglandin and nitric oxide production (13). Both prostaglandin and nitric oxide production in the ductus increase significantly with advancing gestation $(13,27,28)$. Our intention was to examine the effects of PDE inhibition on ductus contractility during development, without the confounding effects of changes in prostaglandin or nitric oxide production. We found that, in the presence of an inhibitor of nitric oxide production, PDE5 inhibition had no effect on ductus tension (Fig. 3). Several endogenous vasodilators (e.g., nitric oxide, carbon monoxide, atrial natriuretic peptide, etc.) are capable of regulating smooth muscle tone in the ductus by activating guanyl cyclase and increasing cGMP production $(27,29,30)$. Our findings suggest that among these cGMP-producing vasodilators, nitric oxide appears to be the most important, because in its absence, inhibitors of cGMP degradation no longer have an effect on ductus tone (Fig. 3). Inhibition of nitric oxide (and cGMP production) may have a direct effect on PDE5 activity itself. PDE5 inhibitors are most effective when the nitric oxide/ cGMP signaling pathway has been activated (31). cGMP binds to a regulatory GAF domain on PDE5; this produces a large stimulatory effect on the PDE5 catalytic domain. Without this effect, PDE5 has only a low intrinsic hydrolytic activity (32).

In conclusion, we observed a developmental increase in both cAMP and cGMP PDEs that contribute to the decreased sensitivity of the late-gestation ductus arteriosus to vasodilators. We speculate that the developmental increase in PDEs may enable the ductus to constrict and remodel itself more efficiently after birth.

Acknowledgments. We thank Ms. Christine Roman for her help with the contractility studies and Ms. Francoise Mauray for the manuscript preparation.

\section{REFERENCES}

1. Clyman RI, Mauray F, Rudolph AM, Heymann MA 1980 Age-dependent sensitivity of the lamb ductus arteriosus to indomethacin and prostaglandins. J Pediatr 96:94-98

2. Clyman RI, Mauray F, Roman C, Heymann MA, Payne B 1983 Effect of gestational age on ductus arteriosus response to circulating prostaglandin $E_{2}$. J Pediatr 102: 907-911

3. Waleh N, Kajino H, Marrache AM, Ginzinger D, Roman C, Seidner SR, Moss TJ, Fouron JC, Vazquez-Tello A, Chemtob S, Clyman RI 2004 Prostaglandin E2mediated relaxation of the ductus arteriosus: effects of gestational age on g proteincoupled receptor expression, signaling, and vasomotor control. Circulation 110:2326-2332

4. Bouayad A, Kajino H, Waleh N, Fouron JC, Andelfinger G, Varma DR, Skoll A, Vazquez A, Gobeil F Jr., Clyman RI, Chemtob S 2001 Characterization of PGE2 receptors in fetal and newborn lamb ductus arteriosus. Am J Physiol Heart Circ Physiol 280:H2342-H2349

5. Manganiello VC, Degerman E 1999 Cyclic nucleotide phosphodiesterases (PDEs): diverse regulators of cyclic nucleotide signals and inviting molecular targets for novel therapeutic agents. Thromb Haemost 82:407-411

6. Soderling SH, Beavo JA 2000 Regulation of cAMP and cGMP signaling: new phosphodiesterases and new functions. Curr Opin Cell Biol 12:174-179

7. Maurice DH, Palmer D, Tilley DG, Dunkerley HA, Netherton SJ, Raymond DR, Elbatarny HS, Jimmo SL 2003 Cyclic nucleotide phosphodiesterase activity, expression, and targeting in cells of the cardiovascular system. Mol Pharmacol 64:533-546

8. Rybalkin SD, Yan C, Bornfeldt KE, Beavo JA 2003 Cyclic GMP phosphodiesterases and regulation of smooth muscle function. Circ Res 93:280-291

9. Polson JB, Strada SJ 1996 Cyclic nucleotide phosphodiesterases and vascular smooth muscle. Annu Rev Pharmacol Toxicol 36:403-427

10. Thebaud B, Michelakis E, Wu XC, Harry G, Hashimoto K, Archer SL 2002 Sildenafil reverses $\mathrm{O} 2$ constriction of the rabbit ductus arteriosus by inhibiting type 5 phosphodiesterase and activating $\mathrm{BK}(\mathrm{Ca})$ channels. Pediatr Res 52:19-24

11. Toyoshima K, Momma K, Imamura S, Nakanishi T 2006 In vivo dilatation of the fetal and postnatal ductus arteriosus by inhibition of phosphodiesterase 3 in rats. Biol Neonate 89:251-256

12. Momma K, Toyoshima K, Imamura S, Nakanishi T 2005 In vivo dilation of fetal and neonatal ductus arteriosus by inhibition of phosphodiesterase-5 in rats. Pediatr Res 58:42-45

13. Kajino H, Chen YQ, Seidner SR, Waleh N, Mauray F, Roman C, Chemtob S, Koch CJ, Clyman RI 2001 Factors that increase the contractile tone of the Ductus 
Arteriosus also regulate its anatomic remodeling. Am J Physiol Regul Integr Comp Physiol 281:R291-R301

14. Clyman RI, Mauray F, Wong L, Heymann MA, Rudolph AM 1978 The developmental response of the ductus arteriosus to oxygen. Biol Neonate 34:177-181

15. Karaki H, Ozaki H, Hori M, Mitsui-Saito M, Amano K, Harada K, Miyamoto S, Nakazawa H, Won KJ, Sato K 1997 Calcium movements, distribution, and functions in smooth muscle. Pharmacol Rev 49:157-230

16. Lee MR, Li L, Kitazawa T 1997 Cyclic GMP causes Ca2 + desensitization in vascular smooth muscle by activating the myosin light chain phosphatase. J Biol Chem 272:5063-5068

17. Savineau JP, Marthan R 1997 Modulation of the calcium sensitivity of the smooth muscle contractile apparatus: molecular mechanisms, pharmacological and pathophysiological implications. Fundam Clin Pharmacol 11:289-299

18. Rybalkin SD, Bornfeldt KE, Sonnenburg WK, Rybalkina IG, Kwak KS, Hanson K, Krebs EG, Beavo JA 1997 Calmodulin-stimulated cyclic nucleotide phosphodiesterase (PDE1C) is induced in human arterial smooth muscle cells of the synthetic, proliferative phenotype. J Clin Invest 100:2611-2621

19. Rybalkin SD, Rybalkina I, Beavo JA, Bornfeldt KE 2002 Cyclic nucleotide phosphodiesterase $1 \mathrm{C}$ promotes human arterial smooth muscle cell proliferation. Circ Res 90:151-157

20. Zhao AZ, Yan C, Sonnenburg WK, Beavo JA 1997 Recent advances in the study of $\mathrm{Ca} 2+/ \mathrm{CaM}$-activated phosphodiesterases: expression and physiological functions. Adv Second Messenger Phosphoprotein Res 31:237-251

21. Kakkar R, Raju RV, Sharma RK 1999 Calmodulin-dependent cyclic nucleotide phosphodiesterase (PDE1). Cell Mol Life Sci 55:1164-1186

22. Netherton SJ, Jimmo SL, Palmer D, Tilley DG, Dunkerley HA, Raymond DR, Russell JC, Absher PM, Sage EH, Vernon RB, Maurice DH 2002 Altered phosphodiesterase 3-mediated cAMP hydrolysis contributes to a hypermotile phenotype in obese JCR:LA-cp rat aortic vascular smooth muscle cells: implications for diabetesassociated cardiovascular disease. Diabetes 51:1194-1200
23. Pan X, Arauz E, Krzanowski JJ, Fitzpatrick DF, Polson JB 1994 Synergistic interactions between selective pharmacological inhibitors of phosphodiesterase isozyme families PDE III and PDE IV to attenuate proliferation of rat vascular smooth muscle cells. Biochem Pharmacol 48:827-835

24. Souness JE, Hassall GA, Parrott DP 1992 Inhibition of pig aortic smooth muscle cell DNA synthesis by selective type III and type IV cyclic AMP phosphodiesterase inhibitors. Biochem Pharmacol 44:857-866

25. Lindgren S, Andersson KE, Belfrage P, Degerman E, Manganiello VC 1989 Relaxant effects of the selective phosphodiesterase inhibitors milrinone and OPC 3911 on isolated human mesenteric vessels. Pharmacol Toxicol 64:440-445

26. Clyman RI, Chan CY, Mauray F, Chen YQ, Cox W, Seidner SR, Lord EM, Weis H, Wale N, Evan SM, Koch CJ 1999 Permanent anatomic closure of the ductus arteriosus in newborn baboons: the roles of postnatal constriction, hypoxia, and gestation. Pediatr Res 45:19-29

27. Clyman RI, Waleh N, Black SM, Riemer RK, Mauray F, Chen YQ 1998 Regulation of ductus arteriosus patency by nitric oxide in fetal lambs. The role of gestation, oxygen tension and vasa vasorum. Pediatr Res 43:633-644

28. Baragatti B, Brizzi F, Ackerley C, Barogi S, Ballou LR, Coceani F 2003 Cyclooxygenase-1 and cyclooxygenase- 2 in the mouse ductus arteriosus: individual activity and functional coupling with nitric oxide synthase. Br J Pharmacol 139:1505-1515

29. Baragatti B, Brizzi F, Barogi S, Laubach VE, Sodini D, Shesely EG, Regan RF, Coceani F 2007 Interactions between NO, CO and an endothelium-derived hyperpolarizing factor (EDHF) in maintaining patency of the ductus arteriosus in the mouse. Br J Pharmacol 151:54-62

30. Toyoshima K, Momma K, Imamura S, Nakanishi T 2007 In vivo dilatation of the postnatal ductus arteriosus by atrial natriuretic peptide in the rat. Neonatology 92:139-144

31. Kloner RA 2000 Cardiovascular risk and sildenafil. Am J Cardiol 86:57F-61F

32. Rybalkin SD, Rybalkina IG, Shimizu-Albergine M, Tang XB, Beavo JA 2003 PDE5 is converted to an activated state upon cGMP binding to the GAF A domain. EMBO J 22:469-478 